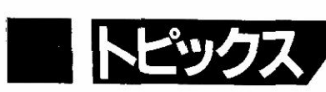

\title{
脂質代謝異常 : 診断亡治療の進歩
}

\section{I. 高脂血症の臨床 \\ 1. 高脂血症の概念之臨床上の問題点}

山本章*

\begin{abstract}
要旨
最近高脂血症の遗伝素因が分子のレベルで次々に解明されて来た，典型は家族性高コレステ ロール血症におけるLDLレセプタ一の欠損であるが，より一般的なものとしてアポEの表現型 のLDL值に対する影響がある。またりポ蛋白リパーゼ遗伝子の解明はIV型やV 型の高脂血症の 本質的な分類を可能にした。ささらに最近ではLp（a）をはじめとして, リポ蛋白と㠜固・線溶系 の関連から見た動脈硬化への影響が注目を集めている。 また高脂血症研究の進歩の特徵の一つ として, 治療の進歩が伴っていることをあげて招きたい.
\end{abstract}

[日内会誌 $81 ： 1739 \sim 1744$, 1992]

Key words : hyperlipoproteinemia, lipoprotein lipase, LDL receptor, apolipoproteins, atherosclerosis

\section{はじぬに}

血浆 (血清) 中のコレステロール濃度が $220 \mathrm{mg} /$ $\mathrm{dl}$ ，トリグリセリドが $150 \mathrm{mg} / \mathrm{dl}$ をこ觉る場合を高 脂血症と呼ぶ。血浆中の脂質はアルブミンに結合 する遊離脂肪酸以外は殆どすべてリポ蛋白という 微小な粒子の形をとって存在するので, 高脂血症 (hyperlipidemia) はすなわち高リポ蛋白血症 (hyperlipoproteinemia)ということになる。但し 高脂血症といら状態でなくても（あるいはそらで あっても), ある特定のリポ蛋白分画，または異常 な組成をもつリポ蛋白分画が増加することがあ り，この様な場合はリポ蛋白異常症 (dyslipoproteinemia)といら術語が使われる。ある特定の リポ蛋白の減少は低脂血症 (hypolipidemiaまた はhypolipoproteinemia) につながることが多い が，これも広い意味ではリポ蛋白異常症に入る。

高脂血症あるいはリポ蛋白異常症はそれ自体が そのまま患者によって病気と認識されるものでは

*やまもとあさら, 国立循環器病センタ一研究所
ない。しかし多くは粥状動脈硬化の強い危険因子 となり，しかも患者が気づくのは重篤な心筋梗塞 に䍜ってからといらのがしばしばである、膵资に つながる高トリグリセリド血症も同様で，しばし ば致命的となるが，膵炎をおこさなければ患者は 高脂血症を自覚しない. そのため高脂血症はsilent diseaseといわれる。

鬼にコレステロールを投与して粥状硬化を作る 実験がAnitchikovらによって行われたのは前世 紀末のことであるが，家族性高コレステロール血 症の家系が先天性代謝異常症の一種として認識さ れたものは今から50～60年前，そしてアメリカや 北欧でコレステロールと虚血性心疾患（冠動脈疾 患) の関係を明らかにするための大規模疫学調查 が始まったのも,アメリカ合衆国に心缄研究所(今 $の$ National Heart, Lung and Blood Institute NHLBIの母体）が設立された1940年代のことで, 高脂血症の歴史は比較的新しい.しかしこの50年 間のこの分野での研究は, 疫学, 診断, 病因から 治療に至るまで著しい進歩を示した。

ノーベル賞を受けたGoldsteinとBrownによる LDLレセプターの発見と並ぶ治療上の重大な貢 
献が遠藤章（当時三共䣨酵研究所）らのヒドロキ シメチルグルタリルCoA (HMG-CoA) 還元酵素 楛抗阻害薬の発見によってなされた。そして今で はこの様な抗高脂血症薬の使用（末たは併用）に よって，虚血性心疾患をはじめとする動脈硬化性 疾患の予防はもとより, 粥状硬化巣の退樎も可能 となった。

以下，1）病因論, 主に分子生物学・遗伝学的に 見た高脂血症の診断と分類,2）動脈硬化のリスク ファタターとしての高脂血症括よびリポ蛋白異常 症，3）治療，の三つについて，主だった問題点を 拾い上げて見ることにしたい。

\section{1. 分子生物学・遺伝学的に見た高脂血症の 病因論的診断法の進歩と今後の展望}

高脂血症は普通, 血浆りポ蛋白のどの分画が増 加しているかによって I 〜 V型（IIはIlaとIIbに 分かれる)の6つのタイプに分類される。しかし 最近は原因の解明，そしてリポ蛋白代謝の全貌が 明らかになるに伴って，たと充ばI型はリポ蛋白 リパーゼ ( $\mathrm{LpL}$ ) 久損症，屯たはアポC-II欠損症， IIa型のらち遗伝性の強いものは家族性高コレス テロール血症 (familial hypercholesterolemia, $\mathrm{FH}$ などと呼ばれる様になった（表 1) 1)。しかし 本当に原因と病態への結びっきがはっきりしてい るのはこの二つだけで，普遍的な高脂血症である 複合型高脂血症 (combined hyperlipidemia, IIb 型)や内因性高トリグリセリド血症 (endogenous hypertriglyceridemia, IV型)の原因はよくわかっ
表 1。遗伝菒因に基つ゚いた血獎りポ蛋白異常症の分類

A) hyperlipoproteinemias

1) familial hyperchylomicronemia (type I hyperlipoproteinemia)

a) familial lipoprotein lipase deficiency

b) apolipoprotein C-II deficiency

2) familial hypercholesterolemia

a) LDL-receptor deficiency

b) mutation of apo B molecule (Arg $3500 \rightarrow$ GIn)

3) type III hyperlipoproteinemia mutation of apo $\mathbf{E}$ molecule in or near the receptor binding domain

4) hyper- or dysbeta-lipoproteinemia due to apolipoprotein $E$ mutations

a) LDL increases in the order of E-2 $\rightarrow E-3 \rightarrow$ E-4 (E-5, E-7)

b) VLDL and remnants (triglyceride) increases in the reverse direction $(\mathrm{E}-4 \rightarrow$ $\mathrm{E}-3 \rightarrow \mathrm{E}-2)$

5) combined hyperlipidemia

6) endogenous hypertriglyceridemia

7) familial type $V$ hyperlipoproteinemia

ていない。

最近，ヘパリン静注後血浆中のLpLの正確な測 定法が開発され，束た，LpLの遺伝子解析が進む炕 つれて，LpL欠損症のへテロ接合体の診断名可能 となり ${ }^{2)}$ ，遺伝性のIV型高脂血症の $1 / 3$, V 型の2/ 3位がLpLの不完全欠損によると推定される様に なった(表 2)，W型高脂血症，あるいは内因性高 トリグリセリド血症は一般にリポ蛋白の合成立進 と処理の低下によると考光られて来たが，処理の

表 2. 高脂血症のWHO現象型別のリポ蛋白リパーゼ欠損症の頻度

\begin{tabular}{l|c|c|c}
\hline $\begin{array}{c}\text { WHO } \\
\text { phenotype }\end{array}$ & $\begin{array}{c}\text { Number } \\
\text { of } \\
\text { Cases }\end{array}$ & $\begin{array}{c}\text { Mean and range of LpL } \\
\text { mass in postheparin plasma } \\
\text { ng/ml }\end{array}$ & $\begin{array}{c}\text { Percentage of } \\
\text { cases with LpL } \\
\text { below 135 ng/ml }\end{array}$ \\
\hline normal & 82 & $209(146-391)$ & $0 \%$ (no case) \\
type I & 6 & $12(6-38)$ & 100 (6 cases) \\
type Ila & 9 & $194(141-234)$ & 0 \\
type IIb & 17 & $182(90-235)$ & $6(1$ case) \\
type III & 4 & $198(111-323)$ & $25(1$ case) \\
type IV & 22 & $154(84-280)$ & 36 cases) \\
type V & 9 & $104(58-214)$ & 78 (7 cases) \\
\hline
\end{tabular}

海田康行他：脂筫生化学研究34：183(日本脂暂生化研究会1992大阪)II-13より. 
低下がLpLの減少によるという証拠はこれまでな かったた゚けに，今後単なる診断だけでなく，合併 症への関連を解析していく上に大いに役立つと考 えられる。特に糖㽷病に伴うこの種の高脂血症の 遺伝的背景を明瞭にすることは極めて重要である が，そのためにも LpL遺伝子異常の解析は不可久 の問題である。

原発性高コレステロール血症 (IIa型高脂血症) の原因としてLDLレセプターの異常が注目を集 めて来だ!. GoldsteinとBrownによってFHはす なわちLDLレセプタ一次損症として定義されて 約10年になるが，これと類似の病態がアポBの異 常 $(3,500$ 番目のアミノ酸の $\mathrm{Asp} \rightarrow \mathrm{Gln}$ 変異)によっ て括こること，欧米で地域によってはLDLレせプ タ一欠損症と同じ位の高頻度に上ることが明らか にされている。但しこの変異はフィンランドや日 本では殆ど存在しない。

最近線維芽細胞やリンパ球を用いて測定した LDLレセプターに全く異常なく，LDLやアポBの 正常レセプターへの結合能にも異常のない原発性 高コレステロール血症 (FH類似)の症例がわれわ れ (Shiba-Harada, M. : Arteriosclerosis印刷中) を含めて 2 - 3 の研究室から報告されている。こ の様な例では肝蔵のレセプターの選択的異常も推 定されるが，姉弟でLDLレセプタ一遺伝子のhaplotypeが異なることからこの推定も成立せず，お そらくはレセプタ一蛋白を発現させる蛋白質の異 常に原因を帰結せざるを得なくなる.Goldsteinと BrownのグループによってLDLレセプター, HMG-CoA合成酵素, HMG-CoA還元酵素の遺伝 子上流に，同じ塩基配列をもちsterol regulatory element之呼ばれる部分のあることが明らかにさ れているが4)，この様な遺伝子の発現調節機構の 解明こそ,上記の症例や，さらに一般的な高コレス テロール血症の原因解明につながると考光られる。

さて，いわゆるFH (LDLレセプター欠損应)で も，血清コレステロール(LDL) レベルが家系あ るいは個体によって大きく異なることがある。直 接FHの遺伝素因に関係するものとしてはLDLレ セプタ一の欠損が完全欠損の、いわゆる receptor negative typeであるか, それともレセプター機能

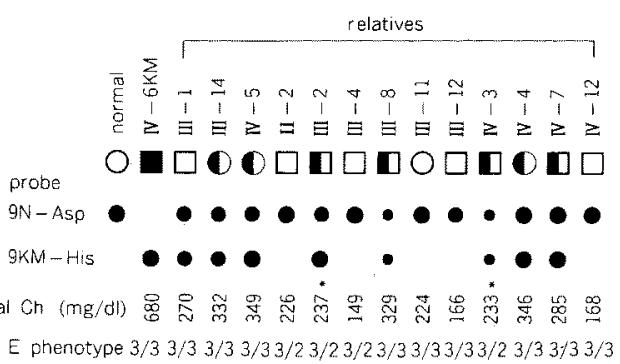

apo $E$ phenotype $3 / 33 / 33 / 33 / 33 / 23 / 23 / 23 / 33 / 33 / 33 / 23 / 33 / 33 / 3$

図 1、家族性高コレステロール血症の一家系に栝ける 家族貝のLDLレセプター異常と血清総コレステロー ル (total Ch) 值.この变異はexon 9内, 第412アミノ 酸の $\mathrm{Asp} \rightarrow \mathrm{H}$ is 点変異で制限酔索断片のblot hybridizationで区別出来る.アポEのphenotype(E3/3と3/2) でtotal Ch值が大きく異なる点に注意

*:E3/2FHであるがコレステロール值は正常値を少 し上まわる程度

が多少残っている receptor defective typeかの違 いがある。たと亲ばわれわれの経験しだ， EGF前 駆体ドメインの欠損した症例では，このレセプ ターがLDLを結合出来ずとも， $\beta$-VLDLの様にア ポEをつ粒子は結合して取り込むことが出来 る.そのせいかこの患者はホモ接合体でも40歳を 過ぎても虚血性心疾患の症状を呈していない。

別の素因の重なり合いでLDL值が大きく影響 されることも多い。やはりわれわれが経験した $\mathrm{EGF}$ 前駆体の中程の点変異の 1 例の家系調査の 結果を図 1 に示す。家族員の中にアポEの表現型 がE $3 / 3$ 人とE $3 / 2$ 人があり, $\mathrm{E} 3 / 2$ 人ではFH へテロ接合体にもかかわらず，絵コレステロール 值が230２40といった正常上限に近い值をとって いる3．一般にアポE2の素因をむつ人は一部その ホモ接合体 (E2/2) の中にIII型高脂血症を発する 例を除くと、より一般的なタイプであるE $3 / 30 人$ よりるLDLは低く, 動脈硬化になり難い。これた 対してアポE4素因の人はLDL值が高く, 虚血性心 疾患の発生率も高いとされている1).

\section{2. 動脈硬化のリスクファクターとしての 血浆リポ蛋白異常}

\section{1) リスクファクターの重複}

FH以動脈硬化に最も泌接に関連する高脂血症 
の典型例である、それでも別に加わる遺伝素因や 環境因子によってかなり大きな個体差が見られ る.すでに述べたアポ現象型以外に，トリグリセ リド値が大さな影響力をもつことが厚生省の原発 性高脂血症調査研究班の調查で明らかにされてい る、環境因子の影響を如実に示す疫学調查の一つ に, Williamsらがアメリカ合㖣国に扎いて世代別 にFHの家族員の寿命をしらべた面白い仕事があ る.開拓時代に苦学した世代の人がFHでる 60〜70歳まで生さているのに，繁栄の時代になる と40歳で多くが心筋梗塞を和こしているといら結 果である5．わが国でもFH木モ接合体の人が何人 か棌を見る京で長生しているといわれるが，この 様な人々の若い時代の食事がどんなであったかを 考壳ると，似た結果といってよからう。

血清コレステロールあるいはLDLと独立した 強力な動脈硬化の危険团子としてlipoprotein（a） (Lp (a)) が強調されている. ThompsonとUtermannが共同して行った調查によって，Lp（a）の 分子量が比較的少さいタイプの人は分子量の大き い上りも Lp (a)濃度が高くこの様な素因が FH に重なると，前者のタイプの人の方が虚血性心疾 患になり易いことが示されている6 . この様に別 の遺伝素因の重なり合いによって動脈硬化の進展 は大きく左右される。この様にして遺伝素因が分 子のレベルで解明されて行くに伴って，何故ある 家系に心筋梗塞㤎多発するかが益々明らかになっ てくるであろう.

以前から動脈硬化に関連する強い因子の一つと してHDLュレステロールの低下が挙げられて来 た。しかし最近，このHDL低下に影響する大きな 因子としてトリグリセりドが強調される様になっ た ${ }^{7) 8)}$. 軽度一中程度のトリグリセリドの増加が動 脈硬化につながることはかなり以前からヨーロッ パ日本の研究者によって強調されていたのであ るが, コレステロールを重視するてかリカ学派に よって見過ごされて来た、トリグリセリドのウェ イトはコレステロール值に依存し, 血禁リポ蛋白 分画としてはいわゆる中間型りポ蛋白IDLやトリ グリセライド richの small LDLの増加に対応す 万.

日本内科学会雜锶 第81巻 第11号・平成 4 年11月10日

\section{2）トリグリセリドと耐糖能低下}

トリグリセリドは純粋のリポ蛋白代謝異常 (VLDL合成・分泌増加京たはその代謝能の低下) によることもあるが，かなりの例が高インスリン 血之耐糖能低下に伴っている. Reavenkよって， 肥満に高血生，耐糖能低下，そして高トリグリセ リドを伴 5 dyslipoproteinemiaを合併するケース がsyndrome Xと名づけられこれらをひき抗こ す元凶として高インスリン血が注目されている。 われわれが調べたretrospectiveの検索でも，高イ ンスリン血之耐糖能低下に伴って冠動脈硬化の進 展することが示唆されている7゙。したがって少し 面倒でも，糖負荷とインスリン值の測定は動脈硬 化関連因子の検查項目の一つとして行っておいた 方がよい.

\section{3）異常組成をもつLDLの存在}

リポ蛋白に話を戻そう。最近アポ蛋白の測定が 日常検查化し，日本は珍しいアポ蛋白欠損症が上 く見つかる国とさえ仲間内からいわ机ている。一 般的に見てアポA-IはHDLコレステロールと，ア ポBはLDL ( +VLDL, IDL) コレステロールに対 応する。ところがSnidermanらによってLDLがそ ら高くなくとすアポBの高い例が動脈硬化性疾患 の人に多いことが強調され, hyperapo Blipoproteinemiaといら名が与支られた。最近 KraussやPatschによって, LDLの粒子が標準サ イズのbのと，これより小ら゙りでトリグリ七りド に富むものの 2 群に分けられ，虚血性心疾患の人 では，要た男性は女性に比べて後者のsmall LDL が多いことが報告された9，どらしてこの様なり ポ蛋白粒子が増え，また動脈硬化に関連するかは まだよくわかっていない，但しLDL中のトリグリ セリドが高くなる機作の一つとしてわれわれは肝 のトリグリセリドリパーゼの活性低下が関与する ことを明らかにした（図2）。

最近この領域に打壮る話題の一つにコレステ ロールェステル転送蛋白欠損によって和こる高 HDL血症がある.これが果して動脈硬化に羅りに くい素因になっているかは興味ある議論の対象で 西り，今後の臨床疫学的調査に興味がもたれる。 馬㴊らによって報告された家系の中で低LDLの 
表 3、検査項目からリ术蛋白異常をよむ

(A) 血清脂筫レベルでの異常

1) 高トリグリセりド(TG)血：TG>150mg/d

$\{$ VLDLの合成穴進

VLDL执よびカイロミタロンのクリアランスの低下 postprandial hyperlipemia(食後の高TG血持続) リポ蛋白リバーゼ( $\mathrm{LpL}$ )の低下(ホモまたはへテロ)

2) 高コレステロール(Ch)血: $\mathrm{Ch}>220 \mathrm{mg} / \mathrm{dl}$

(i) 高LDL血：LDL $=$ 総 $\mathrm{Ch}-\mathrm{HDL}-\mathrm{Ch}-\mathrm{TG} / 5>130 \mathrm{mg} / \mathrm{dl}$

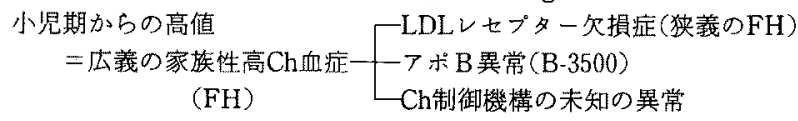

成人してからの(あるい埂人年期以降の)增加

栄養過剩, Ch制御機構のひずみ

フポ $\mathrm{E}$ の影響 $(\mathrm{E} 2 \rightarrow 3 \rightarrow 4$ とCh $\uparrow)$

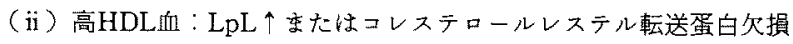

3）低HDL血症：HDL-Ch $<40 \mathrm{mg} / \mathrm{dl}$ アポA-I次損症, Tangier病

高TG血症との関連：HDL-Ch $\doteqdot\left(20+\frac{3000}{\mathrm{TG}}\right) \times \frac{\mathrm{Ch}}{200}$

（B）健常者では極く少ないリポ蛋白分画の增加あるい恃異常りポ蛋白

1) 中間体(レムナント, IDL)の增加

2) $\beta$-VLDL：Ch負荷，アポE2素因(ことにE2/2)

3) small dense $L D L-H \cdot T G L \backslash k$ 関連 $\|$ ? hypothyroidism

4) hyperapo B lipoproteinemia

(C) 高インスリン血，耐糖能低下(上の(A)(B)いずれにも関保)

(D) 血栓関連因子： $\operatorname{Lp}(\mathrm{a})$

高脂血症に伴う PAI-Iの增加

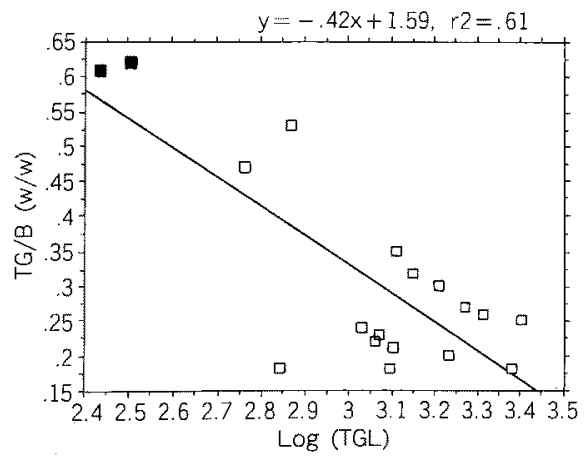

図 2、ヘペリン静注後血浆中の肝トリグリセリドり パーゼ (H-TGL) 量とLDL分画中のトリグリセライド 濃度（本図ではトリグリ七ライド/アポB比）の相関。 大上の 2 例はH-TGL傊症, 他のロで示した例は対照 とした健常人扣よびIV型高脂血症例（山本 章, 池田 康行他：第59回 $\equiv$-ロッ八動脈硬化学会にて発表, 1992. 5, 於 $=-$ ス) .
人が多い一方，松沢らは高 HDL血症のLDLは small denseになっていてLDLレせプターによる クリアランスが低いためむしろ動脈硬化になり易 いのではないかという考光方もある。

スペースのわりに話題を広げ過ぎたので，動脈 硬化につながるりポ蛋白関連諸因子を表にまとめ て招く(表 3 ).

\section{3. 治療：コレステロールとトリグリセリ ドの適正值をめぐって}

欧米でも日本でもコレステロールの正常上限は 200～220mg/dlあたりに設定され，他にリスクの ある人，すでに動脈硬化性疾患に罹っている人で は180mg/dl以下に下げることが推奖されている。 ヒトのコレステロール值は他の動物に比べて異常 
に高い。その理由として，(1)肝臟における合成が LDLレセプター数に比べて高すぎる. (2)血浆中に コレステロールェステル転送蛋白があってLDL をコレステロールrichにしている。(3)肝臓で合成 されるアポBが活涪すべて分子量の大きい $\beta-100$ であるなどが挙げられる，そ机にヒトは本来生 理的には草食動物であって，食餌負荷に対してコ レステロールが上り易くなっているといわれる。 菜食主義者の血清コレステロール值は $150 \mathrm{mg} / \mathrm{dl}$ 程度であり，交た成長期（中学 1 年）男子の值为 この位であることを考党ると，本当の生理的なコ レステロールの適正値はこの辺りと見てよい。た だ良質の動物性蛋白質を充分補給する栄養下では どらしても180mg/dlあたりが下げうる限度とな る.

欧米では最近, 生活条件の改善, 薬物, あるい は部分的回腸バイパス術の様な特殊療法で，動脈 硬化，特に冠動脈病变の改善を目ざした治験成績 が幾つか発表された。 またわが国ではLDLアフェ レーシス療法の効果が発表されて注目を集めてい る10). 予防に関してはまず $220 \mathrm{mg} / \mathrm{dl}$ あたでよい であろうが，治療に関しては思い切って下げる， といらのが現在の大方の見解と考えてよい。

トリグリセリドについては放が国の上限は 150 $\mathrm{mg} / \mathrm{dl}$ に設定されているが欧米ではやっと最近 $200 \mathrm{mg} / \mathrm{dl}$ に設定された所である。おそらくはやが
てわが国の線まで下げられるであるう。

\section{文献}

1) 山本 章：動脈硬化の遗伝素因. 循環器科 31 : 29, 1992.

2）池田康行：LPL と HTGLの分別定量. 医学のあ ゆ2 $157: 781,1991$.

3）三宅康子，山本 章：家族性高コレステロール拀 症．遗后と臨末模查（印刷中） 1992.

4) Smith JR, et al: Identification of nueleotides responsible for enhancer activity of sterol regulatory element in low density lipoprotein receptor gene. J Biol Chem 265 : 2306, 1990.

5) Wiliams RR, et al: Evidence that men with familial hypercholesterolemia can avoid early coronary death. JAMA $255: 219,1986$.

6) Seed M, et al: Relation of serum lipoprotein (a) and apolipoprotein (a) phenotype to coronary heart disease in patients with familial hypercholesterolemia. New Engl J Med 322: 1494, 1990.

7) Yamamoto $A$, et al: Triglyceride and glucose intolerance as a risk factor for coroanry heart disease. Cardiology $78: 185,1991$.

8) Assmann G, et al (edt): The hypertriglyceridemias: Risk and management. Am J Cardiol 68: Suppl A, 1991.

9) Krauss RM : Low density lipoprotein subclasses and risk of coronary artery disease "Cur. rent Opinion in Lipidology". $2: 248,1991$.

10）山本 章: 動脈硬化の退樎 (2). Lipid hepothesis. The Lipid（メディカルビュー社），3:129, 1992.

\section{本号における共通略語}

CETP : cholesteryl-ester transfer protein $コ v x$ テリール・エステル転送蛋白

FH : familial hypercholesterolemia 家族性高 レステロール血症

HDL : high density lipoprotein 高比重リポ蛋白

HMG-CoA : hydroxymethyl-glutaryl coenzyme A ヒドロキシタチルグルタリルコェンザ 1 $\triangle \mathrm{A}$

IDDM : insulin-dependent diabetes mellitus イン スリン依存性糖尿病

IDL : intermediate density lipoprotein 中間 (型) 比重りポ蛋白

LCAT: lecithin cholesterol acyltransferase $\checkmark$ シチンコレステロールアアシルトランス フェ
LDL：low density lipoprotein 低比重りポ蛋白

Lp (a) : lipoprotein（a）リポ蛋白（a）

LPL, LpL : lipoprotein lipase リポ蛋白リパーゼ NIDDM : non-insulin dependent diabetes mellitus インスリン非依存性糖尿病

TG：triglyceride トリグリセリド

VLDL : very low density lipoprotein 超低此重》 ポ蛋白 